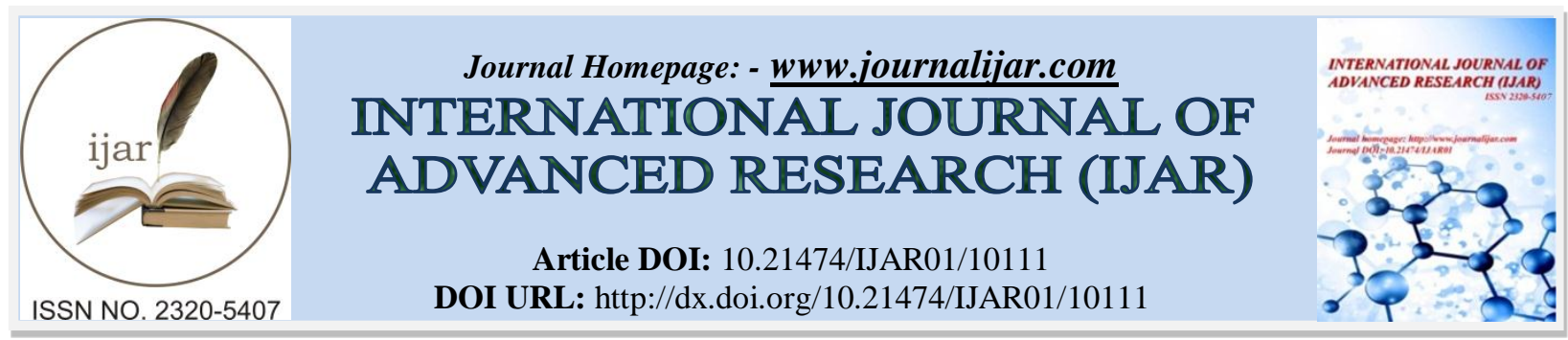

RESEARCH ARTICLE

\title{
IMPORTANCE OF INTRADOMICILIARY PARAMETERS AND POTENTIAL VECTORS ON THE OCCURRENCE OF DERMATOSES IN BRAZZAVILLE.
}

\section{Lenga Arsène ${ }^{\mathbf{1}}$, Lenga Loumingou Ida Aurélie ${ }^{2}$ and Essouli Dégemare Gérardin ${ }^{\mathbf{1}}$.}

1. Laboratory of biodiversity and animal ecology, Faculty of Science and Technology, Marien Ngouabi University.

2. Dermatology and Venereology Service, Brazzaville Hospital and University Center, Faculty of Health Sciences.

\section{Manuscript Info}

\section{Manuscript History}

Received: 14 September 2019

Final Accepted: 16 October 2019

Published: November 2019

Key words:-

Arthropods, dermatoses, health center, indoor living conditions.

\begin{abstract}
Skin diseases are increasingly a public health problem in many countries, particularly in Africa. The dermatoses identified have often revealed various etiologies and many arthropods may be responsible. A study was conducted in the city of Brazzaville, in order to determine the types of arthropods involved in certain immuno-allergic dermatoses and to evaluate the conditions characterizing the aggression of human skin by them. The study was carried out mainly in an indoor nursing home, following consultations at the health center. A total of 43 patients out of a total of 603 people followed were found to be carriers of dermatitis, or $37 \%$ of them. The $\mathrm{H} / \mathrm{F}$ ratio was 0.59 , with an average age of $13.69 \pm 16$ years. Atopic dermatitis was most common with $(74.41 \%)$ followed by Prurigo Strophilus (16.27\%). A total of 668 arthropod specimens were obtained including $96.85 \%$ mites and $3.14 \%$ insects. It appeared that Ixodes ricinus is the most abundant species with a rate of $84 \%$ followed by Blomia tropicalis with $12.7 \%$. The average temperature during the observations was evaluated at $28{ }^{\circ} \mathrm{C}$ while the average humidity was $50 \% \mathrm{RH}$.
\end{abstract}

Copy Right, IJAR, 2019,. All rights reserved.

\section{Introduction:-}

Arthropods are a public health problem in Africa and the world; they represent a real socio-economic burden and their prevalence is growing inexorably (Emodi et al, 2010; OMS,2016). In Africa in general and in Congo in particular, the richness of the flora and fauna, characterized by a large variety of biting insects and mites in the latter case, justifies an in-depth study of the vector agents (Tchouassi et al., 2019).

More than 50000 varieties of mites are currently enumerated and the most common are in house dust, this is the case of species of mites pyroglyphidae and pteronyssidae. Studies show that temperature and humidity are among the factors influencing their life cycle and abundance (Lenga et al., 2013; Boehnke et al., 2017; Alkishe et al., 2017).

In addition, it has been well established that the treatment of certain allergic dermatoses involves the study of the arthropod vectors which are responsible for them, as well as conditions of their transmission (Arlian et al., 2002; Gonzalez-Pérez et al., 2019).

Corresponding Author:-Lenga Arsène.

Address:-Laboratory of biodiversity and animal ecology , Faculty of Science and Technology, Marien Ngouabi University. 
In Brazzaville, Congo, prurigo strophulus ranks first in dermatological consultation in children, followed by atopic dermatitis. The various studies carried out in certain districts of the city ( Lenga et al., 2013) have allowed the identification of numerous arthropods including Ixodes ricinus, Sarcoptes scabiei, Pulex irritans, Simulium albivirgulatum and Cimex lectularius (Lenga et al., 2013; Lenga-Loumingou, 2014; 2015).

We have undertaken to identify the arthropods potentially implicated in the occurrence of dermatoses under indoor conditions.

\section{Presentation of the study environment}

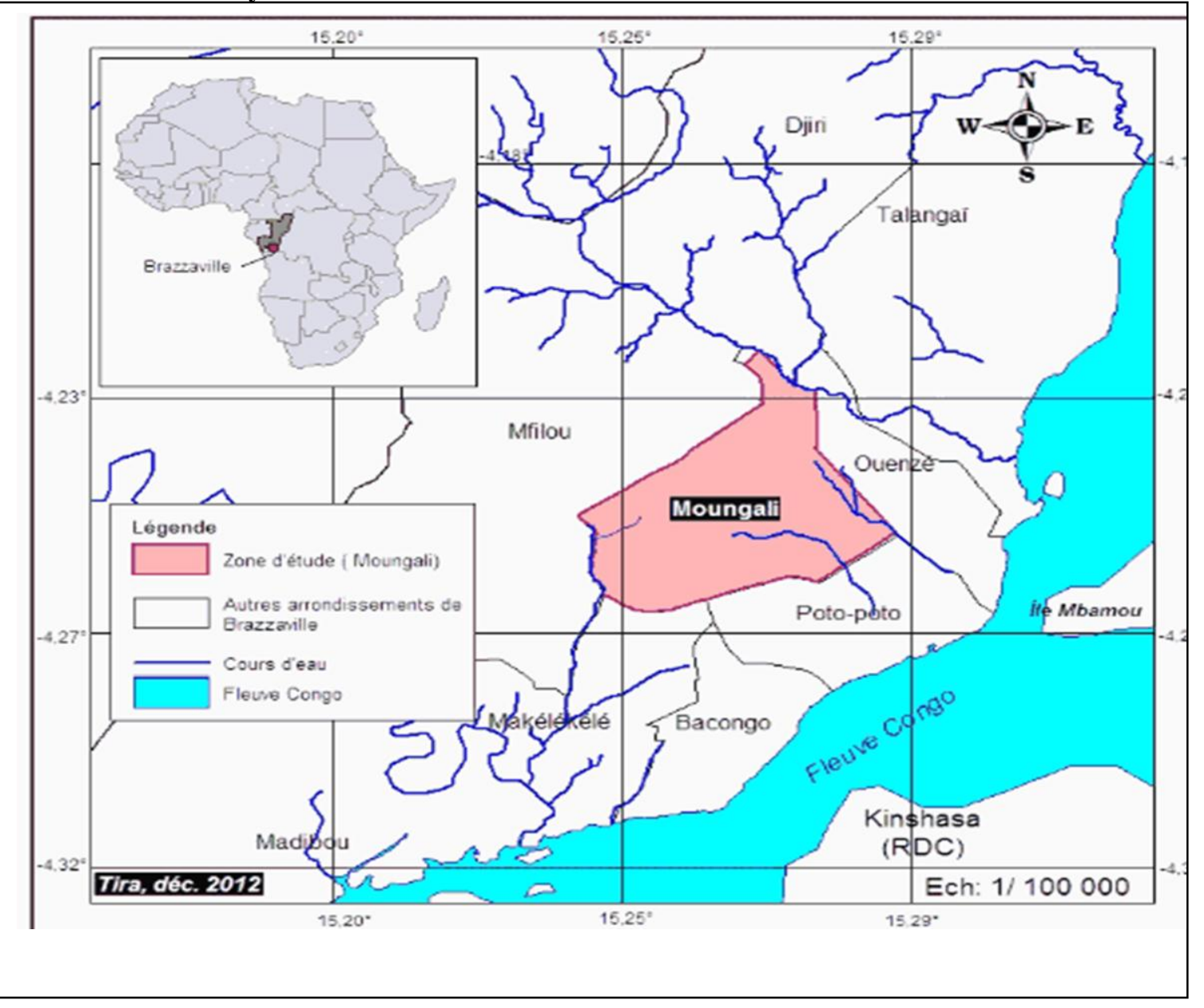

Fig 1:-Location of districts, study sites in the city of Brazzaville

Brazzaville, capital of Congo has an area of $263,9 \mathrm{~km} 2$.It is located between $4^{\circ} 10$ 'South and $4^{\circ} 32^{\prime}$ ' North in altitude and in longitude between $15^{\circ} 16^{\prime}$ 'East and $15^{\circ} 45^{\prime}$ West with an altitude average is 335 meters. The city is bordered on the west by the Congo River which is watered by many tributaries. Average temperatures are $27^{\circ} \mathrm{C}$ in the rainy season and $22.4^{\circ} \mathrm{C}$ in the dry season. The tropical climate is humid and the vegetation encountered is heterogeneous and contains many species of trees, the most common of which are Terminalia superpa, Cassia siamea, Milletia laurenti, Mangifera indica or Kigelia africana, Dolenix regia and Largestromia speciosa

The health center Saint Martin, place of our study for the enumeration of patients in consultation, is located in the district 3 poto-poto. He receives a great multitude of patients coming from the nearest districts. An average of 7600 patients of all sexes and ages are registered annually, according to the admission register. Patients retained in the health center were followed to their homes located in Makelekele, Poto-poto, Moungali, Ouenzé, Talangai, Mfilou and Djiri districts. 


\section{Material And Method:- \\ Equipment}

In the intradomicliary medium, white sheets of dimensions $1.40 \times 1.80 \mathrm{~cm}$ placed under the beds were used for the harvests. $125 \mathrm{ml}$ glass jars and an Oregon Scientific thermo-hygrometer were used in the first case for the conservation of samples collected and in the second case for the evaluation of temperature and humidity variations in homes, In the laboratory, watch glasses, soft forceps and forceps, $70^{\circ} \mathrm{C}$ alcohol, a Leica zoom 2000 binocular loupe and a Visioptic-type optical microscope were used.

\section{Method}

This is a descriptive, analytical and experimental study, carried out from 17 September to 19 November 2018 at the Saint-Martin health center, following the evaluation of the fact sheets provided for this purpose.

Only patients with dermatosis that may have been caused by an arthropod have been selected: these are mainly dermatite atopic, prurigo strophulus, chronic urticaria and scabies. The diagnosis was made by a hospital and university dermatologist. The diagnostic criteria for atopic dermatitis are those of the United Kingdom Working Party.

One out of two patients with one of the selected dermatoses was chosen in order of arrival at the health center and then followed at home for an entomological survey.

Patient cards were then established. They included age, sex, and diagnosis. Similarly, consultation dates such as housing benchmarks were noted.

The consent of the guardians of children was obtained in writing, as well as from the local municipal authorities.

In indoor settings, sessions by home in the bedrooms allowed the collection of specimens from October 5 to November 7, 2018, once a day from 7 am changing homes every 2 days, at the rate of 2 harvests at least in each bedroom. A total of 18 homes were followed.

In indoor settings, sessions by home in the bedrooms allowed the collection of specimens from October 5 to November 7, 2018, once a day from 7 am changing homes every 2 days, at the rate of 2 harvests at least in each bedroom. A total of 18 homes were followed.

Arthropods were captured from dust collected under the beds using a brush scoop. After collection of the dust, the collected arthropods were placed in vials containing alcohol at $70^{\circ} \mathrm{C}$ and then in a watch glass for their observation by magnifying glass and binocular microscope.

The variations of the temperature and hygrometry in the homes were followed at the beginning and at the end of the session, that is 10 minutes after the entrance to the home and 10 minutes before the exit of this one, ( $7 \mathrm{~h}$ and $12 \mathrm{~h}$ ). The identification of the specimens was performed according to the criteria indicated in the dichotomous determination keys (Krantz et al., 2009; Picker et al., 2019).

\section{Results:-}

\section{Epidemiological aspect}

A total of 603 patients were received at Saint Martin Health Center, of whom 114, or 18.9\%, had a dermatosis potentially associated with arthropods. 43 , or $7.13 \%$ a dermatosis of arthropodian origin. Twenty-two (22) of the 43 patients in the health center were followed at home for arthropod research in their homes. The frequency of immunoallergic dermatoses was $37.7 \%$ determined from eighteen (16) men and twenty seven (27) women. The sex ratio was 0.59 with an average age of $13.69 \pm 16$ years.

\section{Clinical aspects}

Atopic dermatitis was revealed as the highest dermatosis with 32 cases or $74.41 \%$, followed by prurigo strophulus with 7 cases or $16.27 \%$ then chronic idiopathic urticaria with 3 cases or $6.97 \%$ and finally of a single case of scabies. 


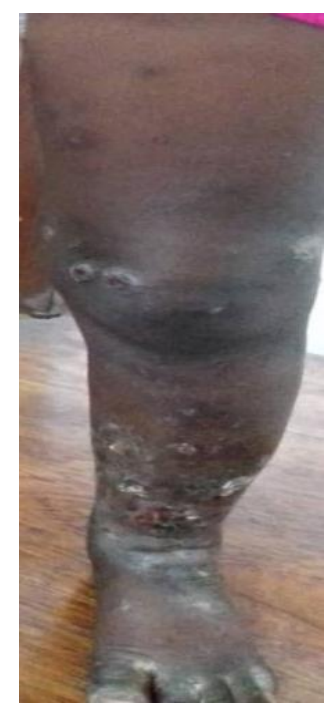

Fig. 2:-Prurigo strophulus impetiginized

\section{Age distribution}

The frequency of potentially immunoallergic dermatoses was high before the age of 10 , rising to almost $40 \%$. She appeared weak from adolescence with nearly $7 \%$ and then fluctuated around $4.6 \%$ throughout the selected ages.

\section{Entomological aspects}

The harvested arthropods concern essentially two taxa: two types of mites, Ixodes ricinus and Blomia tropicalis and two types of insects, Pulex irritans a Siphonaptera and Cimex lectularius, a Hemiptera.

A total of 668 individuals, $96.85 \%$ mites and $3.14 \%$ insects were found in homes, with an average of 30.36 individuals per habitat.

Table I:-Concomitant observation of dermatoses with the arthropods potentially incriminated

\begin{tabular}{|l|l|l|l|}
\hline $\begin{array}{l}\text { Patients followed by } \\
\text { the health center }\end{array}$ & Dematoses observed & $\begin{array}{l}\text { Specimens 1 observed and } \\
\text { incriminated in the } \\
\text { appearance of dermatoses }\end{array}$ & $\begin{array}{l}\text { Specimens 2 observed and } \\
\text { incriminated in the } \\
\text { appearan e of dermatoses }\end{array}$ \\
\hline 01 & Ixodes ricinus & Blomia tropicalis \\
\hline 02 & Arurigo strophulus & Blomia tropicalis & Cimex lectularius \\
\hline 03 & Atopic dermatitis & Ixodes ricinus & $/$ \\
\hline 04 & Prurigo strophulus & $/$ & $/$ \\
\hline 05 & Atopic dermatitis & $/$ & $/$ \\
\hline 06 & Atopic dermatitis & Blomia tropicalis & $/$ \\
\hline 07 & Prurigo strophulus & $/$ & $/$ \\
\hline 08 & Atopic dermatitis & $/$ & $/$ \\
\hline 09 & Atopic dermatitis & & $/$ \\
\hline 10 & Atopic dermatitis & $/$ \\
\hline 11 & Atopic dermatidis & $/$ & $/$ \\
\hline 12 & Atopic dermatitis & Blomia tropicalis & $/$ \\
\hline 13 & Atopic dermatitis & Blomia tropicalis & $/$ \\
\hline 14 & Atopic dermatitis & Ixodes ricinus & $/$ \\
\hline 15 & Atopic dermatitis & Ixodes ricinus & $/$ \\
\hline 16 & Atopic dermatitis & Ixodes ricinus & $/$ \\
\hline 17 & Atopic dermatitis & Ixodes ricinus & $/$ \\
\hline 18 & Chronic urticaria & Ixodes ricinus & $/$ \\
\hline 19 & Atopic dermatitis & \\
\hline
\end{tabular}




\begin{tabular}{|l|l|l|l|}
\hline 20 & Atopic dermatitis & Ixodes ricinus & Pulex irritans \\
\hline 21 & Prurigo strophulus & Ixodes ricinus & $/$ \\
\hline 22 & Atopic dermatitis & $/$ & $/$ \\
\hline
\end{tabular}

A rate of $77.27 \%$ of atopic dermatoses was obtained including $18.18 \%$ of prurigo strophulus. The results obtained indicate that arthropods were harvested in $63.63 \%$ of the patients followed in the homes. Thus, Ixodes ricinus has emerged as the most common and often unique species in homes. In addition, a maximum of three arthropods have been obtained in the concerned homes. The identification allowed to observe essentially two species: Ixodes ricinus and Blomia tropicalis which were the most encountered arthropods with respectively $50 \%$ and $22.7 \%$. The insects Pulex irritans and Cimex lectularius were only found in two homes and always in the company of a mite.

Blomia tropicalis appeared to be associated with prurigo strophulus and the Ixodes ricinus species was associated with atopic dermatitis and chronic urticaria, such as the species Pulex irritans. Cimex lectularius has been found in homes where cases of atopic dermatitis have been observed.

Table II:-Distribution of dermatoses and arthropods as a function of temperature and hygrometry.

\begin{tabular}{|l|l|l|l|}
\hline $\begin{array}{l}\text { Patients } \\
\text { /Houses }\end{array}$ & Hygrometry $(\% \mathrm{RH})$ & Temperature $\left({ }^{\circ} \mathrm{C}\right)$ & Arthropods \\
\hline 01 & 48,5 & 32 & $\begin{array}{l}\text { Ixodes ricinus, Blomia } \\
\text { tropicalis }\end{array}$ \\
\hline 02 & 53,5 & 28 & $\begin{array}{l}\text { Blomia tropicalis, } \\
\text { lectularius }\end{array}$ \\
\hline 03 & 41,5 & 27,5 & Ixodes ricinus \\
\hline 04 & 46 & 32 & $/$ \\
\hline 05 & 48,5 & 29 & $/$ \\
\hline 06 & 59,5 & 28,5 & Blomia tropicalis \\
\hline 07 & 50,5 & 31 & $/$ \\
\hline 08 & 54,5 & 29 & $/$ \\
\hline 09 & 54,5 & 29 & $/$ \\
\hline 10 & 51 & 29 & Ixodes ricinus \\
\hline 11 & 52 & 29 & $/$ \\
\hline 12 & 47 & 29,5 & Blomia tropicalis \\
\hline 13 & 47 & 29,5 & Blomia tropicalis \\
\hline 14 & 53 & 31 & Ixodes ricinus \\
\hline 15 & 50 & 29 & Ixodes ricinus \\
\hline 16 & 51,5 & 27 & Ixodes ricinus \\
\hline 17 & 51,5 & 27 & Ixodes ricinus \\
\hline 18 & 53 & 30 & Ixodes ricinus \\
\hline 19 & 56 & 30 & $/$ \\
\hline 20 & 38,5 & 29,5 & Ixodes ricinus, \\
& & & Pulex irritans \\
\hline 21 & 52 & 30 & Ixodes ricinus \\
\hline 22 & 45 & 30,5 & $/$ \\
\hline
\end{tabular}

The results in Table II show the hygrometry and temperature values noted in the homes visited. The types of arthropods observed are also indicated. This shows an average temperature of $28.09^{\circ} \mathrm{C}$ for all 22 patients visited, as well as an average humidity of $50.20 \% \mathrm{RH}$. The average temperature in households with Ixodes ricinus was $29.2^{\circ} \mathrm{C}$ and the average humidity was $43.9 \% \mathrm{RH}$. By cons for Blomia tropicalis, the temperature fluctuated around $29.5^{\circ} \mathrm{C}$ and the humidity at $51.5 \% \mathrm{RH}$ on average. Pulex irritans proved to be the least common species during these visits.

The comparison of hygrometric and thermal variations in 8 houses including 4 in each of the 2 districts selected, through the Chi-square test, did not show any significant differences, with Moungali and Talangai at 1.029 and 0.094 , respectively, at $p=0,05$. The observed thermal and hygrometric variations therefore have no influence on the number and quality of 
harvested arthropods.

Fig. 3:-Evolution of the patient population with dermatitis according to age groups.

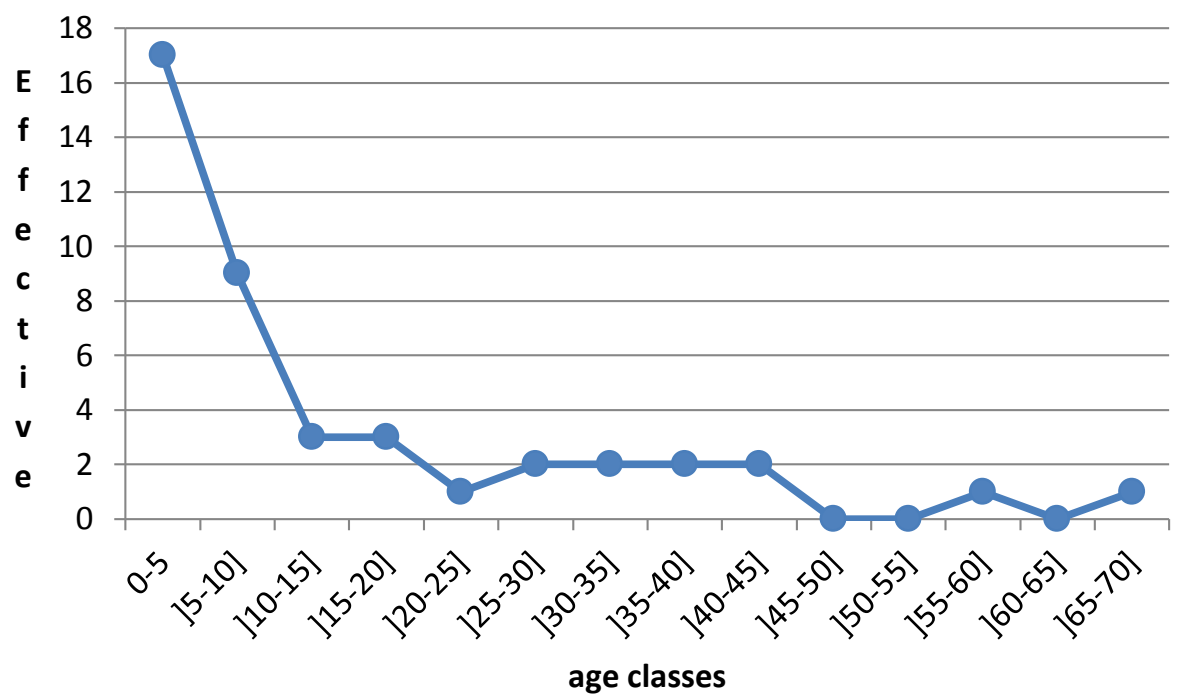

\section{Discussion:-}

The Saint Martin Brazzaville dispensary facilitates access to health care, it is supported by the Congolese government and non-governmental organizations (Dom and GO mission santé, 2015.

In many sub-Saharan African countries, health centers are improving community health. In these centers, the frequencies of reported immunoallergic dermatosis range from 32.5\% in Mali (Youssouf et al., 2016) to 54.76\% in Bukavu (Semikenke, 2018) or 30\% in Bangui (Kobangué, 2014). In our study, immuno-allergic dermatoses accounted for $37.7 \%$ of cases, a rate close to the results obtained by Adegbidi in Cotonou with 37\% [16] or Moussirou-Soumbou in Libreville with 25.1\% (Moussirou-Soumbou, 2018).

The female predominance of immunoallergic dermatoses is classic in the sub-Saharan region (Lenga et al., 2013; Kaloga et al., 2016). In our study, the same type of result was obtained. Dress habits could be the justification.

The average age for the occurrence of dermatoses is 13.69 years in our case. He is 40 years old in the Maghreb [19]. The mode of recruitment could be responsible for these differences.

Atopic dermatitis appeared to be the most common pathology (74.41\%), far ahead of prurigo strophulus (16.27\%), chronic idiopathic urticaria and scabies. In a study by Lenga Loumingou at the University Hospital of Brazzaville, atopic dermatitis accounted for 7.43\%, and prurigo strophulus 7.46\% (Lenga Loumingou, 2014; 2015). Prurigo strophulus is a major health problem in Brazzaville, with a prevalence of $70 \%$ in some districts of Brazzaville (Lenga et al., 2013) and 7.43\% in the Brazzaville University Hospital (Lenga Loumingou, 2014; 2015). Scab was not very present in our study, this rarity could be explained by the periodicity of epidemics (Barete, 2001).

Ixodes ricinus is the most common mite found in patients' homes irrespective of immunoallergic dermatosis, its role in immunoallergic dermatoses has been established. It is one of the most common house dust mites (Honig et al., 2017). Blomia tropicalis was found in 5 dwellings of patients with prurigo strophulus or atopic dermatitis. No study in Brazzaville has previously identified this species, which is frequently implicated in skin and respiratory allergies in sub-Saharan Africa, the Maghreb, South-East Asia and Latin America (Guilleminault et al., 2017). Cimex lectularius and Pulex irritans were least frequent in the habitats of patients with allergic dermatitis.

Dermatophagoides pteronyssimus and farinae, commonly found in house dust, were not found in our study, probably because of the conditions of the study. The temperatures and the humidity in the presence and the conditions of maintenance of the residences probably did not allow their capture. (Arlian et al., 2002). 
On the other hand, the captured insects are few in the habitats followed compared to the mites. As shown in Table II, only two species (Pulex irritrans and Cimex lectularius) were found in our study. Diptera (Anopheles, Aedes, or Simulium) is difficult to explain, perhaps because of their mobility. Their character, especially for the Similium, would push them preferentially outside the homes. However, the high prevalence of prurigo strophulus is attributed to them (Lenga et al., 2013).

The temperature of the study showed a fluctuation of $28.09^{\circ} \mathrm{C}$ on average for the temperatures and $50.20 \% \mathrm{RH}$ on average for the relative humidity. These values are usually favorable to the activation of the Arthropods (Alkishe et al., 2017; Gonzalez-Pérez et al., . 2019)

Other studies have shown that hygrometry between 50 to $80 \% \mathrm{RH}$ is favorable for the proliferation of mites (Medlock et al., 2013). This interval, somewhat different from bears, has been interpreted as favorable to the development of mites. It is likely that the low hygrometry is a factor in the growth of mites, which has been shown to be favorable, from 2000 to 1.5 million mites. a mattress (Pauli et al., 2013).

\section{Conclusion:-}

This study allowed us to show some parameters of the bio-ecology of domestic Arthropods found in the habitats of patients with immunoallergic dermatosis. It also allowed for the first time finding Blomia tropicalis in the habitats of Brazzaville.

This study did not establish the etiopathogenic evidence of these immunoallergic triggering allergic dermatoses. Rather, it has made it possible to identify immuno-allergic dermatoses in a health center in Brazzaville where most common immuno-allergic pathologies are atopic dermatitis, prurigo strophulus, chronic urticaria and scabies.

\section{Bibliographical References:-}

1. Emodi I.J., Ikefuna A.N., Uchendu U., Duru U. Skin diseases among children attending the out patient clinic of the University of Nigeria teaching hospital, Enugu Africa health sciences; vol. $10: 36-6.2010$

2. OMS. Maladies à transmission vectorielle, site officiel, 2016. 33p.

3. Tchouassi D.P.,. Marklewitz M, Chepkorir E., Zirkel F., Agha S.B., Tigoi C.C., Koskei E., Drosten C., Borgemeister C., Torto S, Junglen B., Sang R. Sand Fly-Associated Phlebovirus with Evidence of Neutralizing Antibodies in Humans, Kenya. Emerg Infect Dis. Apr ; 25(4) : 681-690. 2019

4. Lenga A., Lenga-Loumingou I.A., Mabika Moussounda S.M., Vouidibio J... Le prurigo strophulus à Brazzaville : manifestation des vecteurs et étude de quelques paramètres bioécologiques associés. J. Pakistan zool. 45 (1) : 121-128. 2013.

5. Boehnke D., Gebhardt R., Petney T., Norra S.. On the complexity of measuring forests microclimate and interpreting its relevance in habitat ecology : the example of Ixodes ricinus ticks. ParasitVectors.; 10: 549. 6 Nov 2017

6. Alkishe A. A., Peterson T., Samy A. M. . Climate change influences on the potential geographic distribution of the disease vector tick Ixodes ricinus. PLoS One.; 12 (2). 2017

7. Gonzalez-Pérez R., Poza-Guede P., Barrios del Pino Y., Matheu V., Sanchez-Machin I.. Evaluation of major mite allergens from European standardized commercial extracts for in vivo diagnosis : addressing the need for precision medecine. Clinical Translational Allergy. 2019

8. Arlian L.G., Morgan M.S., Neal J.S.. Dust mite allergens : ecology and distribution.. Asthma Rep ; 2 : $404-11$. 2002.

9. Lenga Loumingou I.A.. Profil épidémiologiques des dermatoses au CHU de Brazzaville, Annales Université Marien Ngouabi, 2014, 2015 (3) : 21-25.

10. Krantz G.W., Walter D.E.. A manual of acarology, Third Edition, Texas Tech University Press, , 807p. 2009

11. Picker M., Griffiths C., Weaving A... Field guide to Insects of south Africa.Penguin Random House South Africa. Emily Donaldson Edotor, 2019. 527p..

12. Dom \& GO mission Santé.. Euvre Médicale catholique Sœur Martin, Historique. 95p. 2015

13. Youssouf F., Bekaye T., Adama D., Ousmane F., Siritio B., Lamissa C., Alimata K., Koureissi T., Mamadou B.K., Somita K. Profil épidémio-clinique des dermatoses chez les enfants vus en consultation de dermatologie du centre national d'appui à la lutte contre la maladie à Bamako (Mali). The Pan African Medical Journal V 25. 2016. 
14. Semikenke S., Adégbidi H., Minani J., Bisimwa G. Les dermatoses de l'enfant en milieu hospitalier à Bukavu : aspect épidémiologique et clinique. Annales de Dermatologie et Vénérologie volume 145, issue 4. Page A40. 2018

15. Kobangué L., Lenguébanga P., Dibéré Kamba G. , Guéréndo P., Togué A., Abeyué P., Ya-Poumandji B., Namdito P. Cames Santé vol 2. N¹ Juillet. 2014.

16. Adegbidi H., Dégboé-Sounhin B., Elegbede A., Atadokpèdé F., Koudoukpo C., Akpadjan F., Yédomon H.G., Ango-Panadou do F... Profil épidémiologique et évolutif des dermatoses immuno-allergique chez les enfants en milieu hospitalier à Cotonou. Annales de dermatologie et de Vénérologie volume 139, n¹2S. Page : B139B140. 2012

17. Moussirou- Soumbou G. 1., Zoa A., Mourembou G., Ndojoyi M... Le prurigo strophulus en consultation de dermatologie au CHU d'Angondje au Gabon. Bulletin Médical d'Owendo, journal de la Société Médicale du Gabon. 2018

18. Kaloga M., Kouassi Y.I., Kourouma S., Ecra E.J., Gbery I.P., Gbanama K.K.P., Allou A.S., Ahogo K.C., Kassi K., Kouame K., Sangare A., Yobouet P., Kanga J.M. Aspect épidémiologique et clinique des patients vus en consultation de dermatologie du CHU de Treichville. Annals de dermatologie et de vénérologie volume 143, $\mathrm{n}^{\circ} 4 \mathrm{~s} 1,36 \mathrm{p} .2016$

19. Fatima Ezzahra L., Kawtar B., Bouchra G., Ibtissam K., Karima S., Bardrenine H. , Ohamed Ait O. Bilan d'hospitalisation du service de dermatologie-vénérologie du CHU Ibn Sina Rabat Maroc. The Pan African Medical Journal V7. 2010

20. Barete S., Chosidow O., Bécherol P.et Caumes E.. Ectoparasitoses (poux et gale) et piqures d'insectes. Encyl Méd Chir (Elsevier, Paris), dermatologie, 98-395-A-10, Maladies infectieuses, 8-530-A-10, , 13P. 2001

21. Honig V., Carolan H.E., Vavruskova Z., Massire C., Mosel M.R., Crowder C.D., Rounds M.A., Ecker D.J., Ruzek D., Grubhoffer L., Luft B.J., Eshoo M.W. Broad-range survey of vector-borne pathogens and tick host indentification of Ixodes ricinus from Southern Czech Republic. FEMS Microbiol Ecol. Nov ; 93 (11) : fix129. 2017

22. Guilleminault L., Viala-Gastan C.. Blomia tropicalis : un acarien sous les tropiques. Maladies respiratoires ; 34 (8) : 791-801. 2017

23. Medlock J.M., Hansford K.M., Jaenson G.T.T, Jensen J.K., Jensen P.M., Kazimirova M., Oteo J.A., Papa A., Pfister K., Plantard O, Randolph SE, Rizzoli A, Santos-Silva MM, Sprong H, Vial L, Hendrickx G, Zeller H, Bortel WV. Driving forces for changes in geographical distribution of Ixodes ricinus ticks in Europe. ParasitVectors.; $6: 1.2013$

24. Pauli G. , Bessot J.C. Les acariens : biologie écologique et actualités des allergènes moléculaires. Rec. Fr. Allergol. 53 (suppll) : S45-58. 2013. 